\title{
接合要素を用いた重ね板ばねの有限要素法解析*
}

\section{Analysis of Leaf Springs using Finite Element Method with a Joint Element.}

\author{
浜野 俊雄**, 伊東 正信**
}

\begin{abstract}
Tosio HAMANO $\cdot$ Masanobu ITOH
リーフサスペンション車の乗心地には重ね板ばねのばね定数等が重要な要因となる.本報では, 重ね板ばねのばね定数, 変形挙動等を, 板間接触を考虑して精度良く求めるため, 接合要素を 用いた重斌板ばね専用の有限要素法解析プログラムを開発し，解析を行った。

Riding quality of a vechicle equipped with the leaf suspension is closely associated with a spring rate of the leaf spring and so on. In this worke we examine the analytical properties of the leaf spring, in consideration of a contact between the plates. For a detailed analysis of springrates and deformations in the leaf spring, we have developed a computer program using Finite Element Method (FEM) including a joint element.
\end{abstract}

\section{1. まえがき}

重ね板ばねは,リーフ(ばね板)を数枚重ねてばねと して用いる物で，古くから鉄道車輛，自動車などの影 架装置に使用されている。重ね板ばねに関するばね定 数や応力等の解析は, 展開法や板端法が良く知られて いる. 展開法は, 重なり合うリーフが互に全面接着し, 中央から同一位置にある点の各リーフの曲率がすべて 等しいとの仮定に基づき, 各リーフを一平面上に展開 して一枚の板と等価であるとして計算する方法である. 板端法は, リーフから隣接するリーフへの力の伝達が, リーフ先端(板端)だけで行われるという仮定に基づく 計算法である。これらの計算法は, いずれも材料力学 の真值ぐなはりの微小変形理論に基礎をおいており, 計算が簡単で, 得られた結果の誤差は実用上差し支え ない程度であったことから，設計の基本式として広く 実用されてきた1)。

しかし, これらの計算法は, 各リーフの形状を真直 ぐな板と仮定したり, リーフ間の接触(板間接触) 状態 を板端だけに限定する等, 一面的な仮定の基に解析を 行っている. そのため, 実際には板端以外での板間接 触を生じる様なセンターボルトの締付けや胴締女過程, あるいはへルパー(補助ばね板)の板間接触により非線 形特性を得ているプログレッシブなどの解析を行う場 合, かなり限定されたものとなる。 また, 特に履歴曲 線における対角線ばね定数を解析的に求めるためには

原稿受付日 1991 年 9 月30日

* ばね技術研究会1990年度春季講演会にて発表

** (㧣)日発グループ中央研究所 (NHK Spring R\&D Center)
板間接触，特に摩擦を考虑する必要がある。このよう に, 重ね板ばねの解析には解決しなければならない課 題も多い. 特に板間接触の解析的取り扱いを可能にす ることは重要な課題である。

そこで本報では，まず，各リーフの形状を実際に即 して取り扱えるようにするため有限要素法を導入した。 さらに，板間接触を板端に限定することなく取り扱う ため各リーフ間に接合要素を挿入する有限要素法解析 プログラムを開発し一連の解析を行ったので報告する。

なお，重ね板ばねへの本解析の適応性を確認するた め, 一部解析と実測との比較も行った。その結果, 今 回履歴曲線の解析に必要である摩擦については考慮さ れていないが，板間接触を接着・離隔状態で判定する ことで，荷重特性について比較的良い結果を得た。

\section{2. 解析の概要}

\section{1 重ね板ばねのモデル化}

有限要素法により解析を行う場合，モデル化に用い る要素の特性は解析精度等に大きく影響する。重ね板 ばねの各リーフは板厚が一定のものがほとんどであっ たが，最近では板厚がテーパ状のいわゆるテーパリー フが多くなっている．有限要素法でテーパリーフを取 扱う場合, 一定の板厚で段階的に近似する方法が良く 取られる。この方法で解の精度を上げようとすると要 素分割数が多くなり，それだけ演算時間も長くなる。

そこで，本報では，テーパ形状をそのまま取扱える ように, しかも解の精度を落とさないで要素分割数を 少なくできるようにするため, テーパ形状のはりに適 用する要素剛性マトリックスを新たに求めて用いた。

図 1 に，重亦板ばねの胴締状態を対象とした解析モ 
デルの模式図を示す。重ね板ばねの各リーフは前述し たテーパ形状のはり要素によるモデル化を行い，板間 接触が生じると考えられる\# 1 と\# 2 あるいはパッドの 間には次項 (2.2)で述べる接合要素を插入した。

2.2 接合要素と接触判定

板間接触に摩擦を考慮しようとすると問題は複雑で ある。ところが，摩擦を無視し，接触を接着・離隔状 態だけで判定するのであれば，線形解析プログラムを 少し修正するだけで斉む。そこで，本報では摩擦は考 慮せず,接着状態での摩擦係数は $\mu=0$ として取り扱つ た.

ところで，有限要素法で接触問題を取扱う場合，筆 者の知る限りでは, 接触面に連続条件を用いる方法 ${ }^{2)}$ 特殊要素を晴入する方法 ${ }^{34) 55}$ がある。後者の方法 の問題はどの様な特性の要素を接触面に插入するかで ある。本報では後者の方法を用い，重ね板ばねの板間 に接合要素として三角形平面要素系のものを挿入した。 接合要素としてトラス系のものを用いることも可能で あるが, 変形に伴う節点間のずれ(要素座標系における 垂淔方向の節点間相対変位)が余り大きい場合には適さ ない.その点, 平面要素系のものは節点間のずれが幾 分大きい場合にも対応できる利点がある。プログレッ シブ重亦板ばねのへルパーにおける板間接触では, 変 形に伴う節点間のずれも大きく，重ね板ばねの板間接 触には接合要素として平面要素系を用いる方が適して いる。

図 2 は，接合要素として三角形面要素系を用いたと きの接合要素と接触判定方法を示したものである. $t_{1}$ と $\mathrm{t}_{2}$ はリーフの板厚, $\mathrm{h}^{\prime}$ は三角形要素の変形前の高さ, $\mathrm{h}$ は変形後の高さである。接触判定は要素内の応力 $\Delta \sigma$ と 三角形の高さ $\mathrm{h}$ にっって行う.今回摩擦係数は $\mu=0$ で あるから，接着状態にあるリーフ間ではリーフに対し 垂淔方向の荷重のみを伝達することになり，水平方向 はすべり状態となる。
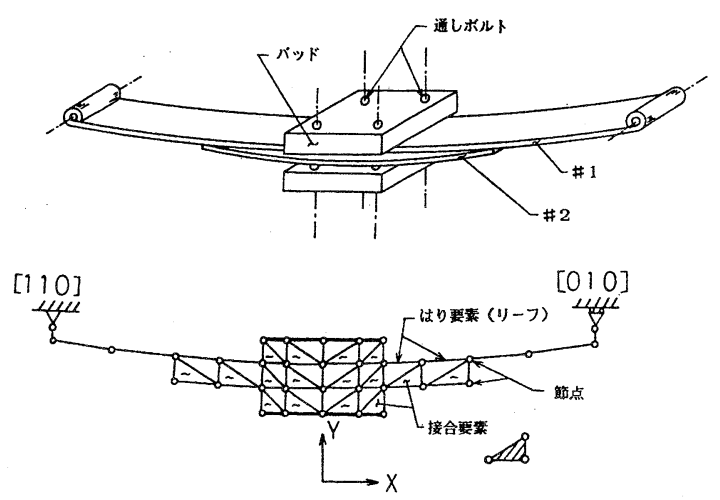

図 1.重ね板ばねの解析モデル

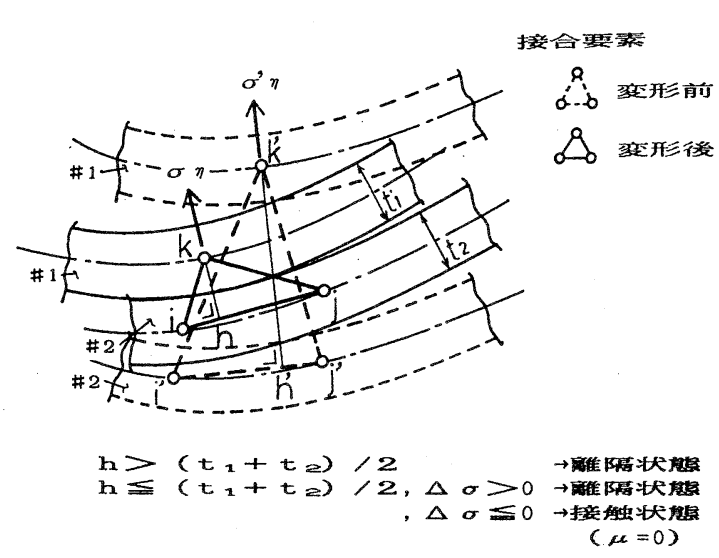

図 2. 接合要素と接触判定

\section{3 解析の流れ}

解析は有限要素法に基づき, 繰返し計算は荷重增分 法により行なった。 以下, 繰返し計算について述べる.

まず，接合要素の節点座標から幾何学的に接触して いるか否かの判定を行なう。このとき判定された接触 状態は荷重増分過程で接着状態か離隔状態に変化する ため，まだ決定的ではない，そこで，一時的に，幾何 学的に接触していると判定された接合要素はすべて接 着状態であると仮定して, 試験的に荷重を与え計算を 行なう。その時の各接合要素の応力を求め, その值に よって荷重増分過程での接着・離隔状態の判定を行な う。もし, 接着状態の仮定を満足しない接合要素があ つた場合には，仮定を変更して再計算を行ない，すべ ての接合要素が仮定を満足するまで繰返し, 荷重增分 過程での接触状態を決定する。

次に, 決定された接触状態で荷重増分を行なう訳で あるが, 新なに次の接合要素が幾何学的に接触状態に なるまでの荷重増分量は未定である。そこで, 試験的 に与えた荷重からその時の各接合要素の節点変位を求 め, 節点座標と節点変位とから接触状態になるまでの 比率を各接合要素について計算する。その中で比率の 最小の接合要素が, 次に最も早く接触状態になること になる。すなわち, 求める新なな荷重増分量は試験的 に与えた荷重に, 各接合要素の比率の中から最小の值 を乗じて得られる。

以上の荷重増分毎に有限要素法解析を行ない, 所定 の荷重になるまで繰返す。

\section{3. 解析例}

ここでは重ね板ばねの解析の一例としていわゆるコ ンベンショナルを取り上げた. 図 3 にその解析モデル を単体状態掞よび締付状態について示す. 単体状態と は胴締めを行う前の状態のことである。各リーフの形 状は円弧の一部とした。なお，胴締め用の上下パッド 


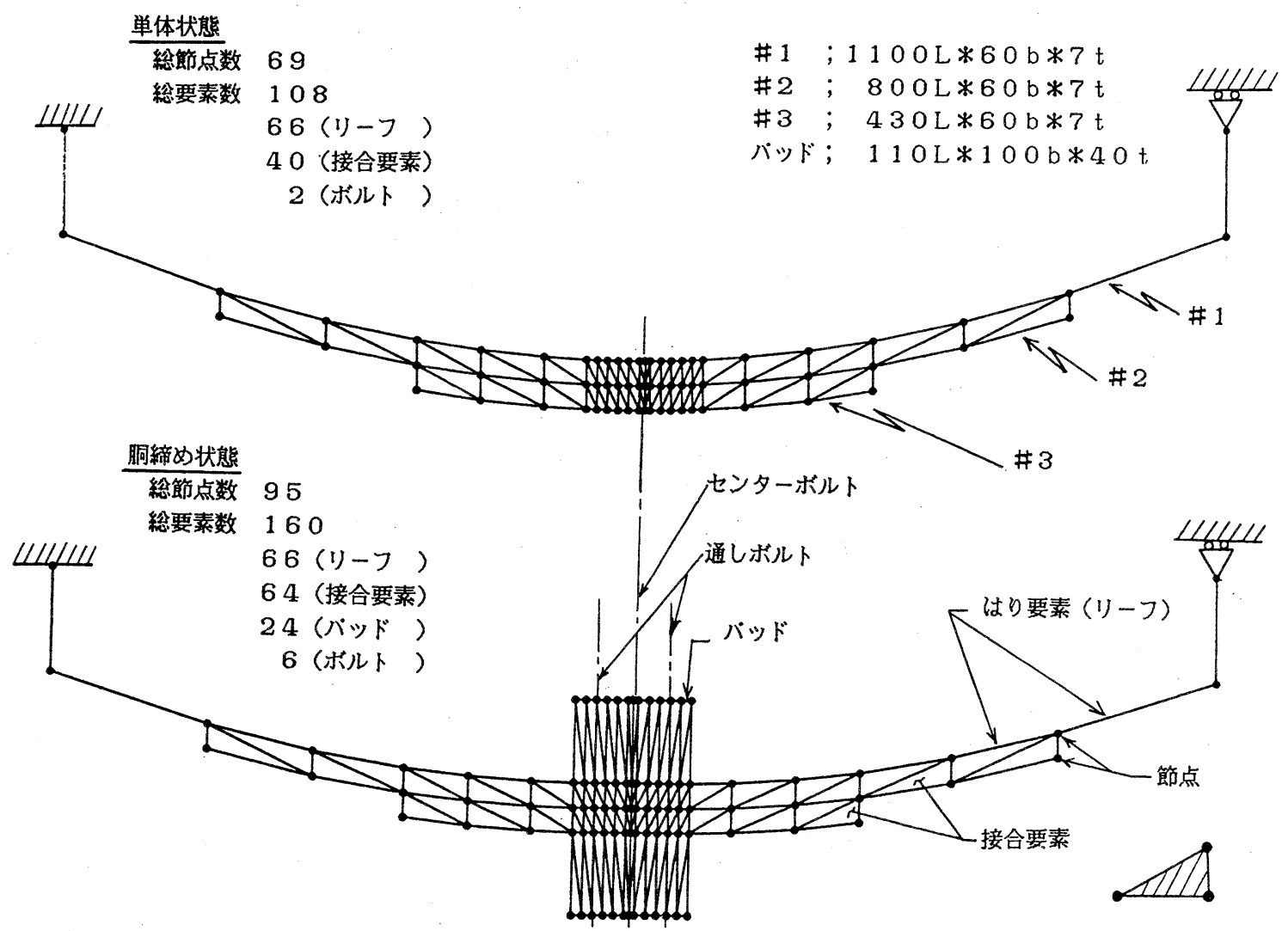

図 3.コンベンショナル重ね板ばねの解析モデル

は, 唫験で用いた板厚40tの鋼板をモデル化の対象とし た。

ところで，重ね板ばねの各リーフの形状は，リーフ を重㸚たときニップと呼ばれる板間隙間ができるよう に決められる。そのため, 組み付けの際にセンターボ ルトを締付けるとリーフは変形し，いわゆるニップ応 力が生じる。このとき, 通常\#1(メインリーフ)の表面 には压縮応力, \#2 あるいは\#3の表面には引張応力が 発生し, 負荷を受けた時, \#1 を保護する効果があると 言われている。また，センターボルトで組付けられた 後, 車に取り付けるため胴締めと呼ばれる上下パッド での締付けが行われる。このときもリーフは変形し， 応力が生じる。すなわち胴締めされた状態で車に取り 付けられ，使用時に負荷を受けることになる。このよ うに重斌板ばねはリーフ単体から組み付け，胴締め，
図 4 から図 6 は負荷後の最終的な応力分布を示して いる. 図 4 は単体状態, 図 5 と図 6 は胴締状態につい てのものである。図 5 に扔いて胴締め内部の発生応力 は胴締めされない他のリーフ部分に比べて低い。これ はパッドの締付けの影響によるもので，胴締め内部で はリーフの変形が拘束されているからである。なお, 胴締女内部の応力はリーフ形状, あるいはセンターボ ルトの締付け, 胴締めの強さの程度 (ボルトの締め具合 いによっても異なってくる.

そして負荷の各過程でそれぞれ変形し，各リーフに㐫 力が発生する。本報では，これらの各過程に添ってそ れぞれ解析を行い, 変形状態と変形後の応力分布を評 価した．特に負荷後の最終的な評価は各過程の重数命 せによった。 


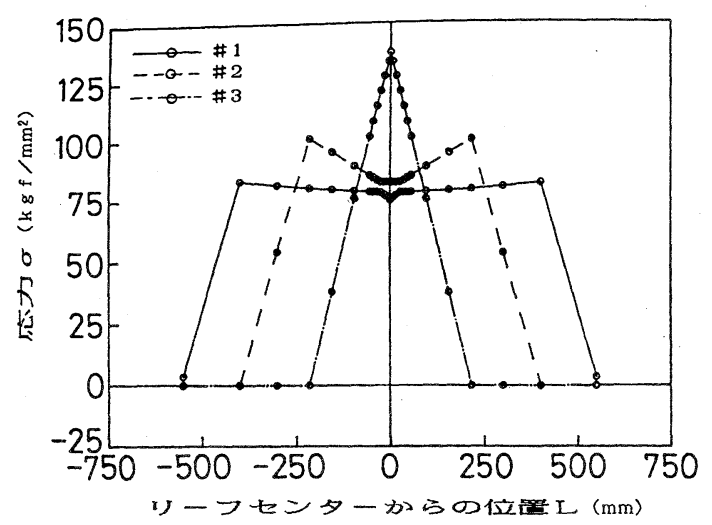

図 4 。単体状態での負荷による応力分布

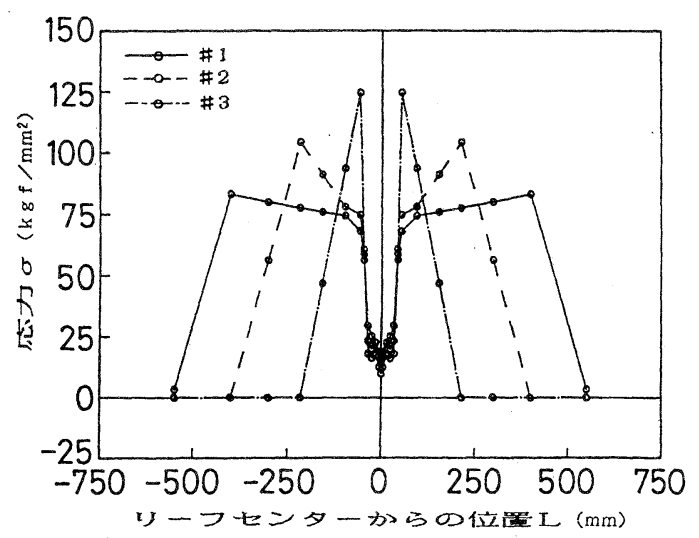

図 5 . 胴締め状態での負荷による忘力分布

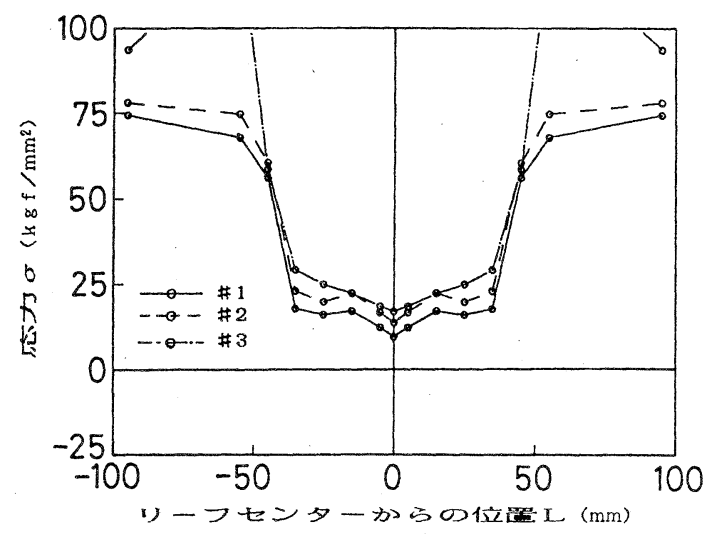

図 6。胴締如状態での負荷による応力分布 (パッド内の詳細)

\section{4. 重ね板ばねへの適用}

ここでは，重权板ば权に本解析を適用したときの垁 月性を確認するため，重效板ばるの代表的な以下の 2
つのタイプについて解析を行った。荷重とたわみの関 係については解析值と実測值との比較も行った。お， ここで解析に用いた各りーフの形状は形状測定装置に より実測したものである。実験での胴締めは，板厚 40 $\mathrm{mm}$ の鋼板をリーフの上下に当て 4 本の通しボルトで 締め付けた。

（1）コンベンショナル重ね板ばね

このばねは重ね板ばねの最も代表的なタイプで，線 形特性を期待して使用される.

図 7 から図11はコンベンショナル重ね板ばねに関す る解析結果である。四 7 は単体状態における負荷過程 の変形図で, 図 8 は締付状態における負荷過程の変形 図について示している。図 9 は荷重とたうみの関係で 単体状態と締付状態についてそれぞれ解析值と実測值 の比較を示している。両状態とも解析值と実測值とは 良く対応しており，“本解析の実用性が確認できる。ま た，図 9 において，ば衫定数は単体状態(○，破線）に 比べ締付状態 $(\bigcirc$ ，実線)の方が高くなっている。これ は胴締めの影響によるものである。なお，実測値は板 間摩擦の影響により負荷と除荷との間にヒステリシス を生じているが, 解析では摩擦は考虑されておらず $\mu=$ 0であるからヒステリシスは得られていない。

図10と図11は負荷により各リーフ表面に発生する応 力分布の解析結果で，リーフセンターからの位置に対 して示したものである。困10は単体状態で負荷を受け た場合で，四11は締付状態で負荷を受けた場合につい てのものである。四11と第 3 章の図 5 を比較した場合, 胴締め内部の応力分布は図11がかなり複雑である。こ れは, 図 5 のリーフ形状が円弧の一部であるのに対し て図11のリーフ形状は実測によるものであるからであ る。このことから，板間接触を取り扱う場合，リーフ 形状の精度が応力分布に敏感に影響すると考えられる。

(2) プログレッシブ重る板ばね

このばるは，へルパーと呼ばれる補助板の順次接触 を利用した非線形特性を期待して使用される。

図12から図16はプログレッシブ重ね板ばねに関する 結果である。図12と図13は変形図，図14は荷重とたわ みの関係で，図15と図16は解荷後の応力分布を単体状 態と締付状態についてそれぞれ示したものである。特 に困14の荷重とたわみの関係ではコンベンショナルと 同梯，解析值と実測值とが良く対応しており，プログ レッシブについても本解析の実用性が確認できる。ま た,プログレッシブの特徴はヘルパー（H 1)の挙動であ る. 図11の変形困において, ヘルパーは負荷を受ける とリーフ中央から板間接触が始り，負荷に伴って板間 接触の位置は板端に移動する。これによって荷重とた わみの関係は非線形となる。このとき，ばね定数は単 体状態上り締付状態の方が高くなっており，胴締めの 影響がプログレッシブにおいても確認できる。 


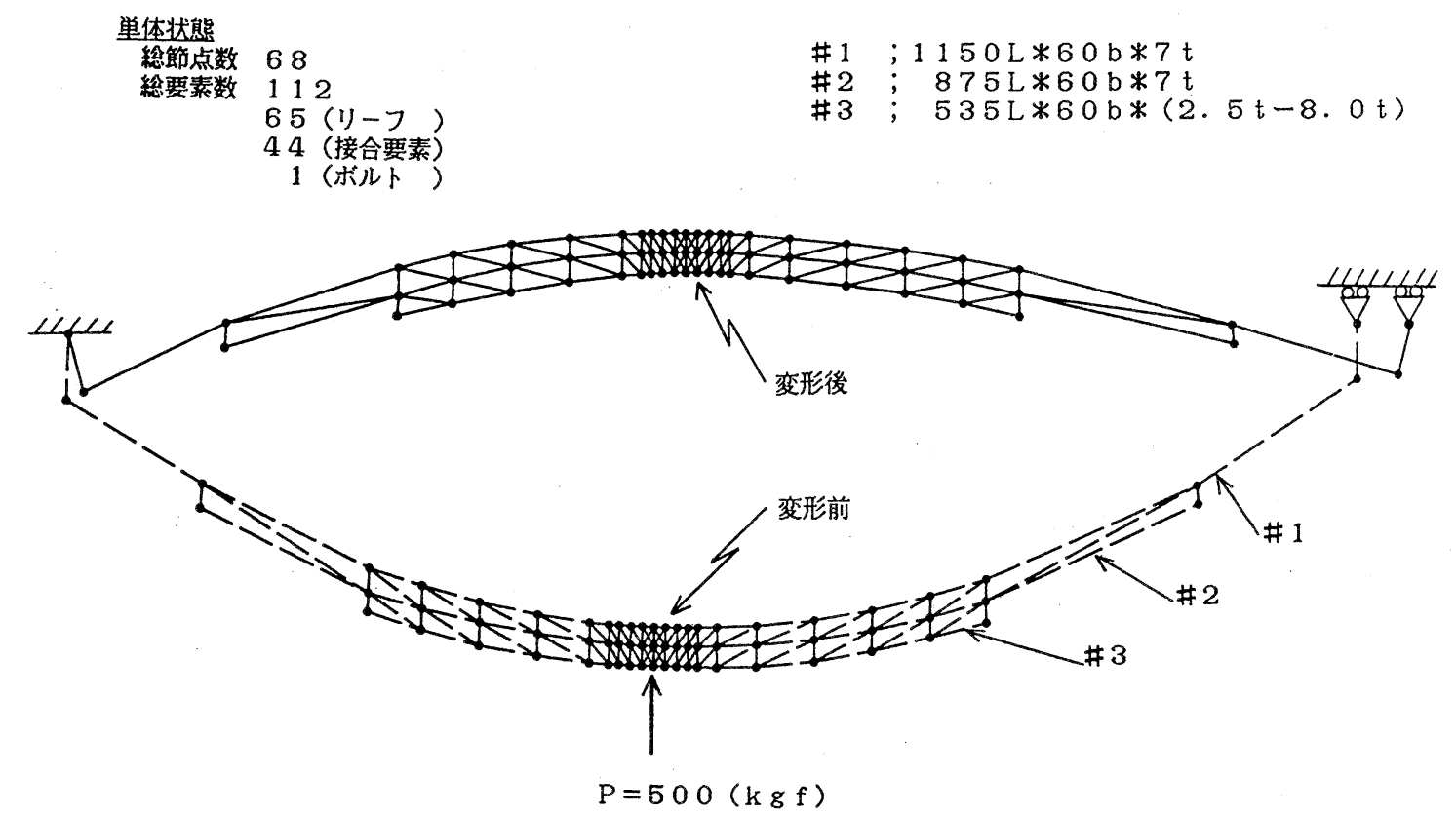

図 7.コンベンショナル重ね板ばねの単体状態での真 荷による変形

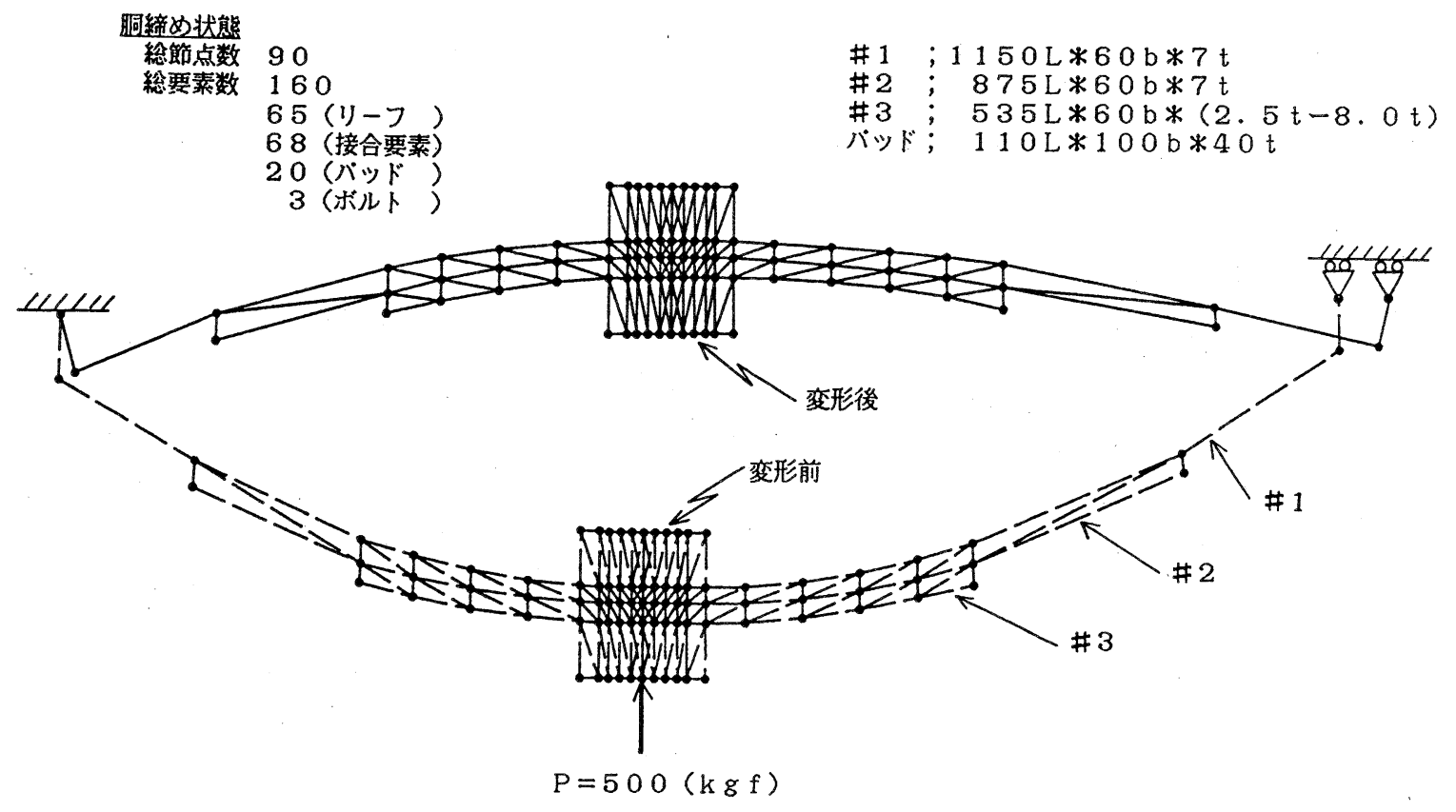

図 8.コンベンショナル重ね板ばねの胴締め状態での 負荷による変形 


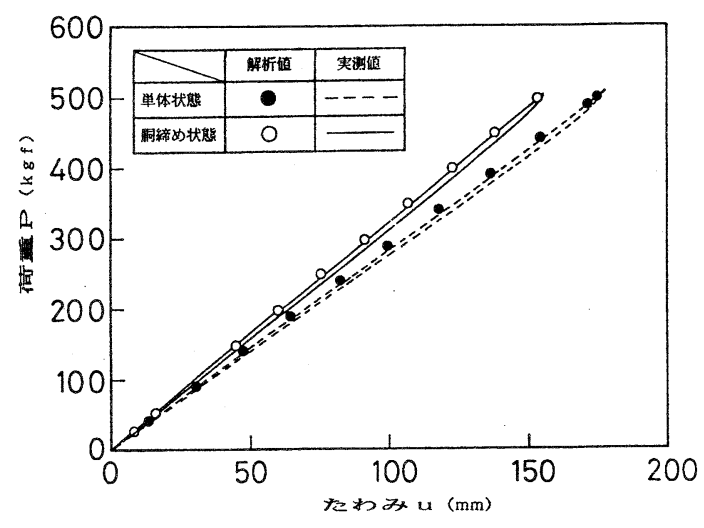

図 9.コンベンショナル重ね板ばねの荷重とたわみの 関係

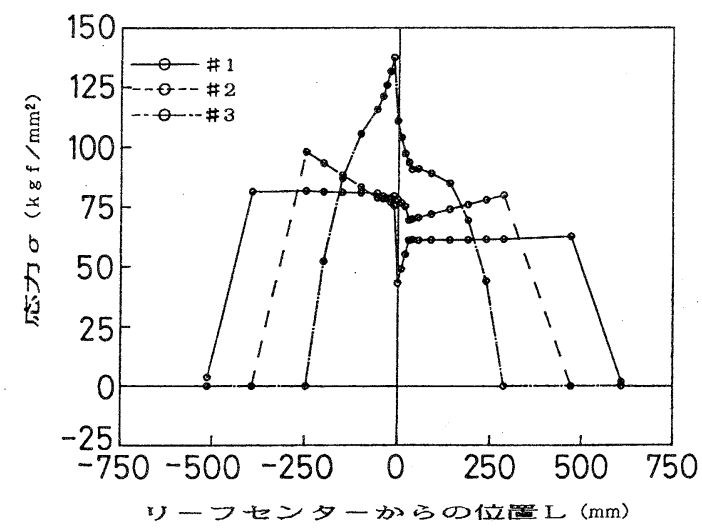

図10.単体状態での負荷による応力分布

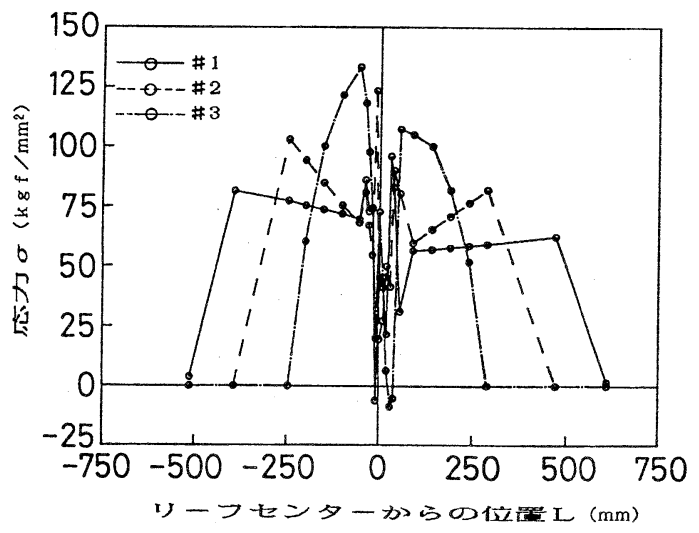

図11.胴締め状態での真荷による応力分布

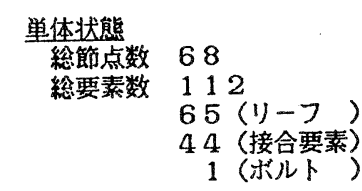

\#1;1200L*60b*8t

\#2;1030L*60b*8t

H $1 ; 850 \mathrm{~L} * 60 \mathrm{~b} *(6.3 t-16.0 \mathrm{t})$

4 (接合要素)
1 (ポルト)

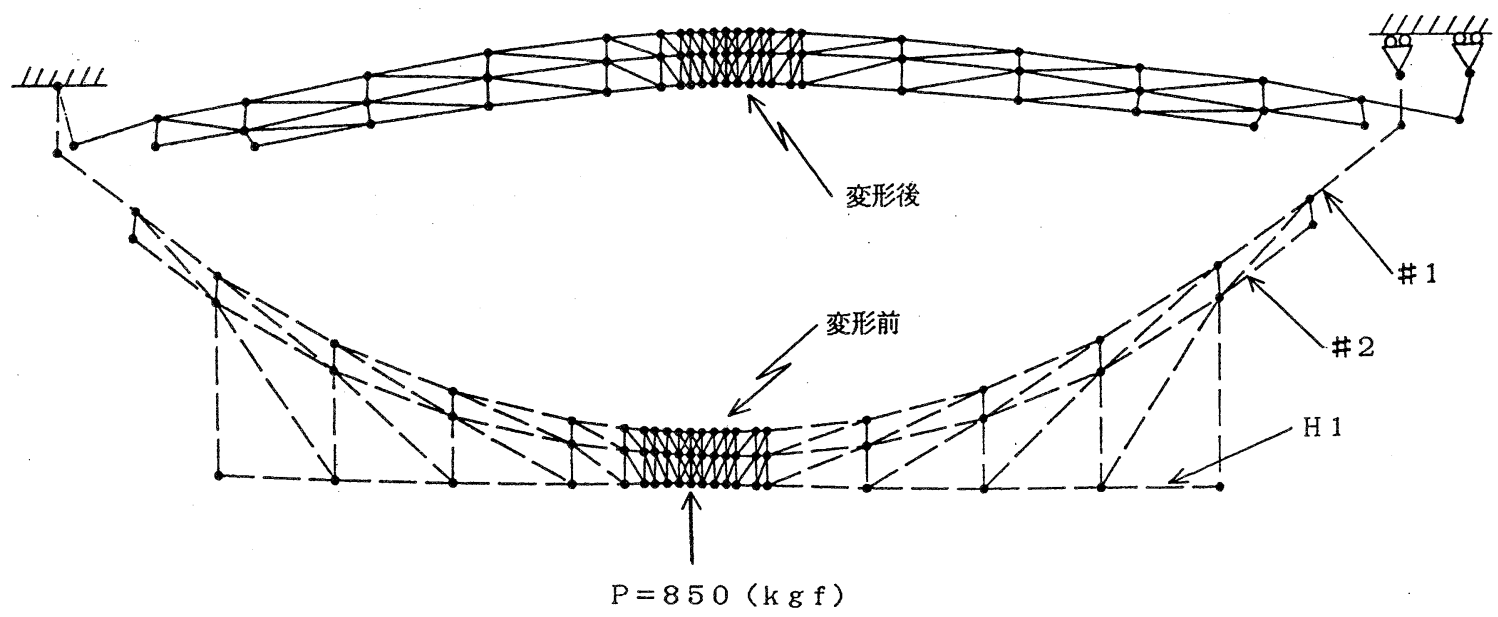

図12.プログレッシブ重ね板ばねの単体状態での負荷 


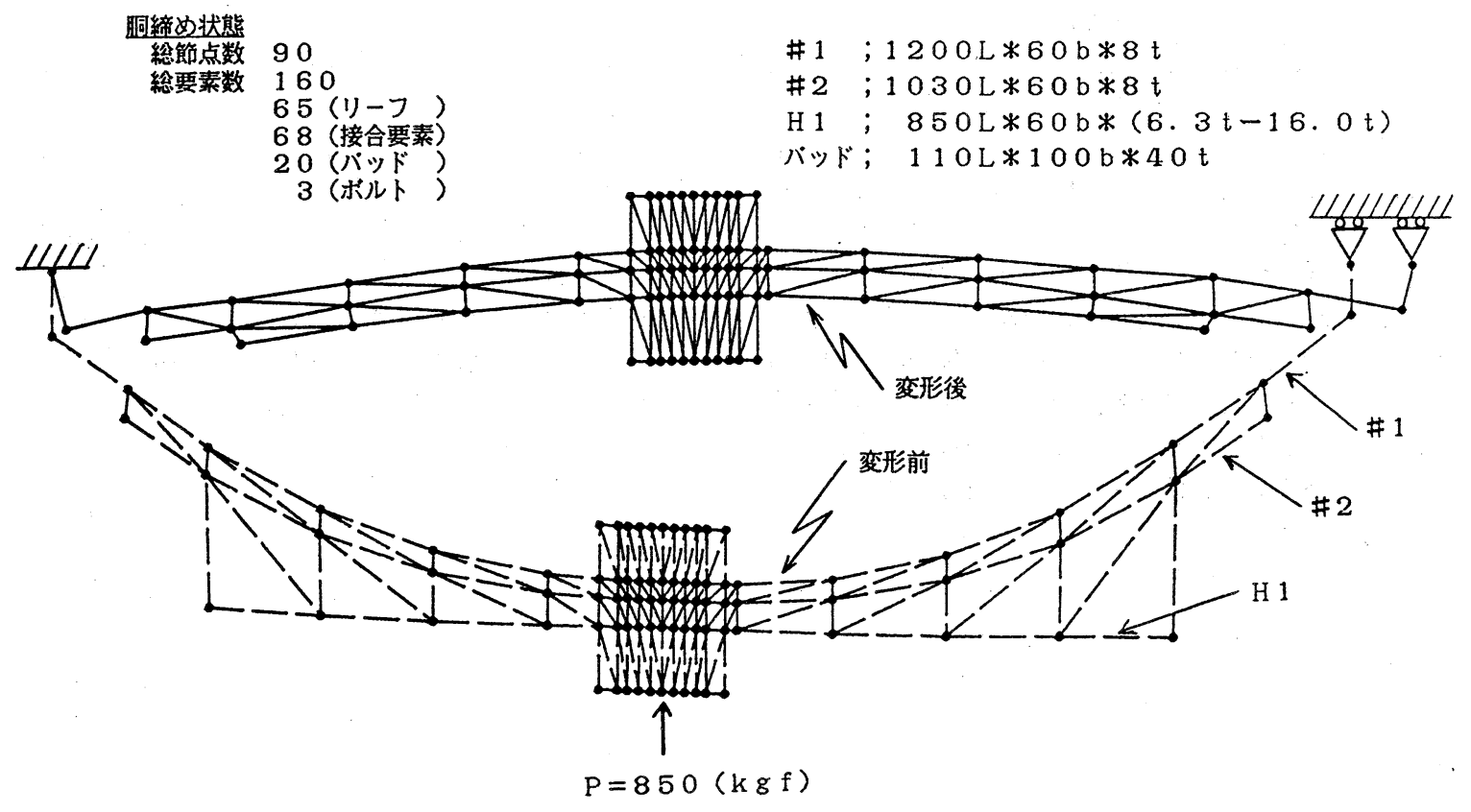

図13、プログレッシブ重ね板ばねの胢締め状態での真

荷による変形

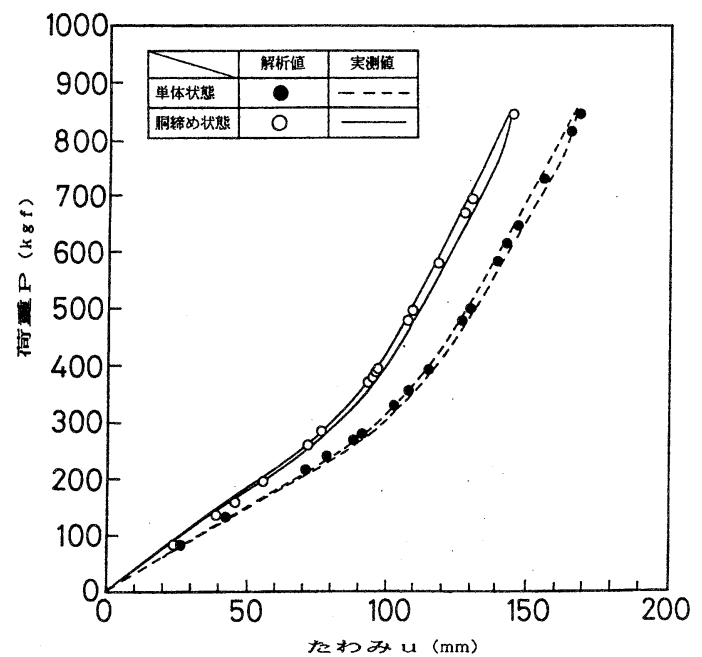

図14、プログレッシブ重ね板ばねの荷重となわみの関 係

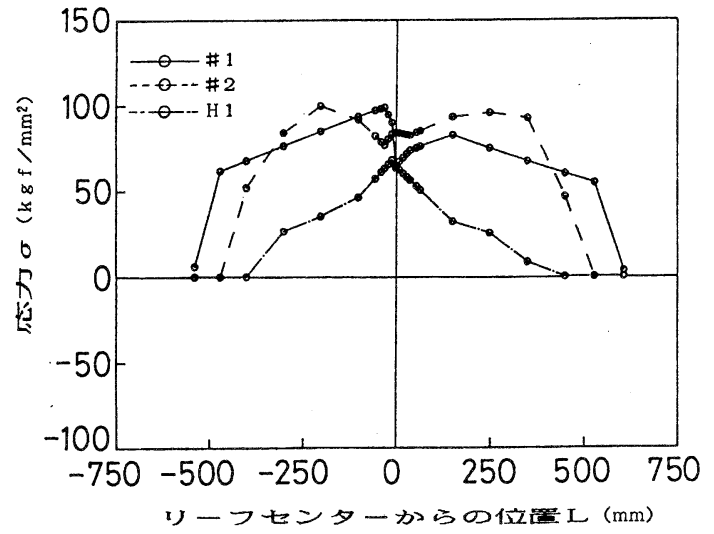

図15. 単体状態での負荷による応力分布

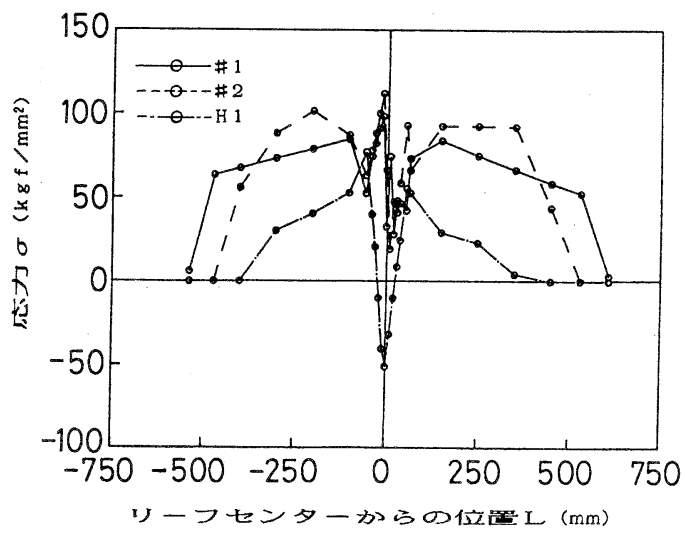

図16.胴䋨女状態での負荷による応力分布 


\section{5. あとがき}

重ね板ばねを対象とした,リーフ間に三角形面要素 系の接合要素を插入して板間接触を取り扱う有限要素 法解析プログラムを開発し解析を行った。本解析によ れば，重㸚板ば效のリーフ単体の形状を基にセンター ボルトの締付け過程から胴締为過程を経て負荷に至る までを一貫した方法で解析することが可能である．し かも，板端法などでは取り扱えなかった胴締め過程の 解析なども可能となり, 胴締め内部の接触状態や応力 分布等も知ることができる。 なお，本報での接合要素 は平面要素系を適用しているため, 今後摩擦状態を取 り扱う接合要素へと拡張することも可能である.
参考文 献

1) 第 3 版「ば齐」，ばね技術研究会編(昭和57年), [丸善]

2 ) 大手敏：日本機械学会論文集, 38 巻313号 (昭和 47 年), 2210

3 ）下関正義, 磯貝一秀：ばね技術研究会昭和 57 年 度春季講演会前刷り, p.5.

4 ）丸井英男：日本鋼構造協会第11会研究集会, 又 トリックス 解析法研究発表論文集 (1977), 253

5 ）山田嘉昭, 江澤良考: 生産研究, 31 巻 6 号 (1979), 519 